\title{
Introduction to Rethinking Rorty's Pragmatism: Ethics after Epistemology
}

Michela Bella and Chris Voparil

\section{OpenEdition}

1 Journals

\section{Electronic version}

URL: http://journals.openedition.org/ejpap/1842

DOI: 10.4000/ejpap.1842

ISSN: 2036-4091

\section{Publisher}

Associazione Pragma

\section{Electronic reference}

Michela Bella and Chris Voparil, «Introduction to Rethinking Rorty's Pragmatism: Ethics after Epistemology », European Journal of Pragmatism and American Philosophy [Online], XII-1 | 2020, Online since 16 June 2020, connection on 24 September 2020. URL : http://journals.openedition.org/ejpap/ 1842 ; DOI : https://doi.org/10.4000/ejpap.1842

This text was automatically generated on 24 September 2020 .

\section{$(\mathbb{\theta} \Theta \Theta$}

Author retains copyright and grants the European Journal of Pragmatism and American Philosophy right of first publication with the work simultaneously licensed under a Creative Commons AttributionNonCommercial-NoDerivatives 4.0 International License. 


\title{
Introduction to Rethinking Rorty's Pragmatism: Ethics after Epistemology
}

\author{
Michela Bella and Chris Voparil
}

1 We are in the midst of a reevaluation of Richard Rorty's pragmatism. The last few years have seen a spate of new books on Rorty. ${ }^{1}$ This year alone two critical anthologies already are out and two more are in preparation. ${ }^{2} \mathrm{~A}$ new volume of previously unpublished philosophical papers by Rorty will be released in a few months (see Rorty 2020). The intensification of interest since his passing in 2007 spans the globe and shows no signs of abating. Spurred in part by a new generation of readers of American philosophy who have come to the classical figures of pragmatism through Rorty and harbor no preexisting antipathies, the scholarly reception of Rorty as an unhelpful interloper who did as much to distort as to revive the tradition is giving way to fruitful dialogues, constructive engagements, and immanent critiques from which we can learn. Readers are patiently distinguishing Rorty's more outrageous side from his penetrating insights and incisive criticisms (see Rey 2017). The long delayed "new stage of creative and scholarly work on pragmatism and the several pragmatists," which one commentator predicted, back in 1982, Rorty's work would initiate, now finally is upon us (Brodsky 1982: 333).

2 The title of the symposium, "Rethinking Rorty's Pragmatism: Ethics after Epistemology," expresses the central aim of this issue: to continue the conversation about the consequences for ethics of Rorty's famous critique of modern epistemology and its well-known concern with knowledge and representation. The issue features new work that seeks to challenge the divides between and among "classico," "paleo," “neo," and "new" pragmatisms, by rethinking the interconnection of ethics and epistemology through, with, or beyond Rorty's pragmatism. The opening article of our symposium is Giovanni Maddalena's "Rorty as a Legitimate Member of the Pragmatist Family," which is a critical update of the legitimacy of Rorty's membership in the pragmatist family. Reexamining many criticisms, which mainly focused on Rorty's problematic 
relationship with Peirce's philosophy, Maddalena detects "family resemblances" between their conceptions and suggests three core topics that prove how Rorty shared central aspects of the classical pragmatists' common project. These topics are Rorty's anti-Kantism, the "synthetic drive" animating his philosophical attitude, and his transformative view of philosophy. On the first aspect, Maddalena claims that one can be more precise than Rorty in assaulting Kantianism in the name of antifoundationalism for "the real problem with the Kantian picture of philosophy, a good representative of the modern tradition of philosophy, is that foundation according to Kant has to be necessary and a priori." Maddalena is cautious about Rorty's opportunity to extend his criticism of Kantism to modernity tout court, and accuses Rorty of a certain preconceptual historicism. Indeed, Maddalena envisages the possibility of a convergence between Rorty's and Peirce's views on the basis of the mind-world continuity mathematically investigated by Peirce, and what Maddalena defines as Peirce's a posteriori foundationalism. With regard to the synthetic drive in Rorty's philosophy, Maddalena acknowledges his profound affinity with the "tendency of the entire classic movement to go beyond the analytic frame that encompasses the epistemology of modern philosophy." However, he considers Rorty's exclusive preoccupation with Kantism a limitation on the possibility of rethinking a new epistemology and a new metaphysics in a renovelled synthetic perspective. Finally, moving from "systematic philosophy" to "edifying philosophy," in a transformative sense, and therefore open to political commitment, for Maddalena Rorty's attack on the separation between the fields of inquiry diverges from classical pragmatists. In the end, Maddalena finds that Rorty underestimates the role of inquiry in his reading of classical pragmatism, and of Dewey in particular.

3 Four articles concentrate on Rorty's discussion of epistemology, addressing in new ways different but interconnected topics. In "Does Rorty have a Blindspot about Truth?," David Macarthur analyses the controversial role normativity plays in Rorty's conception of truth. He presents his criticisms of several major objections to Rorty's position, mainly engaging in direct discussion with Huw Price. Macarthur's defence of Rorty from Price's "off-target" argument that "Rorty's norm of communal warranted assertibility suffers the same fate as the norm he calls personal warranted assertibility, namely, that without a distinct norm of truth neither norm can make sense of improvements in one's epistemic standing whether in terms of the actual community or future extensions and improvements of it" is particularly sophisticated. Against Price's static or majoritarian conception of justification, Macarthur calls on Rorty's dynamic conception of justification and the normative pressure deriving from new methods of inquiry, or what Macarthur defines as his "progressive perfectionist conception of communal norms." Once we renounce the familiar misinterpretation of Rorty as having a majoritarian conception of justification, Price's criticism loses its strength. Nonetheless, Macarthur identifies another blindspot in Rorty's conception of truth, which is the lack of coherence in first-person reflection. He argues that Rorty's notion of truth needs to be complemented by specific attention to the norm of consistency as an integral part of the truth-commitments required by any rational system of beliefs. What, however, survives any criticism and perhaps is Rorty's greatest legacy, is his neopragmatist perspective about truth - namely, his acknowledgement of the "embeddedness of truth in our linguistic and interpretative practices."

4 Michela Bella's “The Interlacing of Science and Ethics: Rorty's Critique of Epistemology for a Pragmatist Hermeneutics" focuses on Rorty's hermeneutical understanding of 
science and ethics, and their relation, as a way to investigate his pragmatist reshaping of hermeneutics. Bella insists on the Jamesian and Deweyan element in Rorty's perspective as deeply inspired by their holistic-syncretic understanding of pragmatism. In this perspective, she identifies an "eirenic strategy" that emerges in Rorty's approach to moral and scientific issues, which is the result of his movement from epistemology to hermeneutics. The Rortyan reformulation of scientific rationality aligns particularly with the Jamesian intent of confronting scientific dogmatism by questioning the key notion of truth and reconsidering the opposition between scientific and ethical beliefs. Rorty's personal and historical conception of ethics contrasts with the notion of scientific rationality elaborated in modernity - a notion he harshly criticizes as still belonging to an epistemological worldview - as something that, unlike morality, is able to escape human finitude and contingency. Within a naturalistic hermeneutical framework, Rorty contests the ontological need for necessary connections or disconnections between moral and scientific discourse. Bella's proposal to read Rorty's appropriation of hermeneutics along the lines of his recovery of pragmatism may contribute to renovating the current lines of debate around Rorty and pragmatism, especially by reevaluating Rorty's strong cultural connection to the American philosophical tradition and his commitment to making this pluralistic voice relevant again to contemporary conversations.

5 In "Pessimistic Fallibilism and Cognitive Vulnerability. Richard Rorty as an Example," Ángeles J. Perona affirms that rather than rejecting rationality and truth, Rorty's pragmatism is consistent with a fallibilist model of rationality. However, it differs in an important sense: instead of establishing epistemological fallibilism in relation to truth and objectivity and then extending it to all forms of rational activity, Rorty's fallibilism emanates from an ethical stance. For Perona, Rorty's fallibilism "does not focus so much on the permanent possibility of error and the consequent impossibility of achieving unconditional truths, as on the ethical objective of avoiding any relapse into authoritarianism." Perona offers a frame for usefully evaluating Rorty's attention to ethics and social relations in the notion of cognitive vulnerability, a broader category than fallibilism which entails an awareness of "the limitations of our cognitive abilities and the conditions to exercise them," including conditions of power and domination that perpetuate forms of epistemic injustice. Ultimately, she finds that while Rorty "bases the norms of all rational interaction on a democratic social ethics developed on the existential background of vulnerability," his fallibilism is unduly pessimistic as a result of its reduction of all appeals to the evidence of experience as authoritarian and his related inability to see even the epistemic activity within normal conversational exchanges as playing a role in altering the conditions that give rise to vulnerability.

In "Two Forms of Realism: Making Sense of Rorty's Controversy with Brandom and Ramberg over Objectivity," Yvonne Hütter-Almerigi sheds welcome light on an intriguing, Rorty-inspired debate among both neopragmatists and New Pragmatists that turns on the relation of realism, representationalism, and objectivity. Specifically, she interjects several key clarifications regarding Rorty's perplexing insistence that there is a difference between Robert Brandom's notion of "made true by facts" and the idea of "getting things right," which Bjørn Ramberg spurred Rorty to accept. As HütterAlmerigi explains, there is a substantive change in Rorty's stance in his 2000 response to Ramberg: where he previously held that there are only causal word-world relations, after Ramberg he recognizes that there are non-causal, though non-representational, relations as well. She pinpoints the precise locus of this shift in a change in Rorty's 
understanding of Davidson's conception of triangulation that seemingly moves Rorty closer to Brandom. Yet she helps us understand why this is not the case: Brandom's perspective retains a representational scheme which entails distinct realms for unconceptualized reality and our application of concepts. Brandom's sense of objects as non-perspectival has "ontological aspirations" that Rorty rightly objects to for its implicit reliance on a scheme-content distinction. For Rorty, claims are not "made true by facts," but instead are based on the Davidsonian triangle. That is, where Brandom relies on a conception of facts beyond vocabularies to secure objectivity, the view Ramberg and Rorty accept gets there via successful vs. unsuccessful interactions with the world. Hütter-Almerigi holds that for Rorty, "Claims do not have to 'get things right' beyond vocabularies since if we 'get things right' we cope successfully with our peers and the world." Fully understood, Rortyan redescription does not absent reality; rather, it rearranges our attention by altering causal dispositions that in turn affect reality.

7 Emil Višňovskýs expansive, in-depth elaboration of "Rorty's Humanism: Making it Explicit" helpfully contextualizes the neopragmatist's humanistic and Romantic commitments in relation to a wide historical array of humanists, both within and outside the pragmatic tradition. His reading expands our understanding of Rorty's humanism to encompass not only the standard romantic fare but the pragmatist notion of human "coping" with reality and his antirepresentationalism. Even Rorty's metaphilosophical orientation is informed by "his reaction to what can be termed the anti-humanism of professional philosophy." Rorty's ethnocentrism, which entails that "Philosophers must reflect on who they are as members of a particular, historically concrete community and culture," for Višňovský also is a "pillar" of his humanism. Višňovský affirms Kate Soper's identification of the elitism and gender-blindness endemic to Rorty's humanism, while raising questions about her assumption that Rorty's anti-realism is incompatible with humanism. Rorty's humanism holds that "we should turn from nonhuman to human reality in our social practices." It is not a stretch to understand Rorty's entire philosophico-political project, including both its epistemic and ethical commitments, as an effort to realize a humanistic culture. Višňovský argues for extending Rortyan humanism into our current post- and trans-humanist era, while at the same time recognizing its limitations around the role of non-linguistic experience and its cordoning off of individual self-perfection in the private sphere and of liberal democracy in the public.

In perhaps the most comprehensive account to date of what Brandom has called "the 'vocabulary' vocabulary," Mauro Santelli's "Redescribing Final Vocabularies: A Rortian Picture of Identity and Selfhood" highlights the relative lack of attention this signature concept received by Rorty himself, as well as the absence of agreement among commentators about how to interpret the notion of final vocabularies. Santelli gathers together the insights Rorty offers for a "pragmatic naturalist conception" of moral identity, but also raises critical questions regarding Rorty's privileging of final vocabularies in his understanding of self and identity - why are words more central than beliefs and desires, which Rorty elsewhere made central? He helpfully disaggregates the implicit Wittgensteinian, Sellarsian, and Davidsonian commitments entailed by Rorty's understanding of vocabularies, their relation to social practices, and their normative import. Introducing conceptions from George Herbert Mead and from sociolinguistics, Santelli generates additional clarity regarding this widely-known yet elusive category of Rorty's. Specifically, understanding final vocabularies as subsets of 
our "sociolects and idiolects" enables us to grasp Rorty's contribution: "just as Rorty can be considered as linguistifying a pragmatist theory of identity in which the social is primitive like Mead's social psychology, he can also be considered as moralizing sociolinguistic considerations about the relationship between speech and identity." Words, Santelli holds, offer more flexible and pluralistic ways of marking our relation to communities and are a better measure of what we share, than beliefs. He then illuminates how Rorty's way of thinking about vocabularies and narratives of moral identity provides resources for understanding the entanglement of speech and devalued social status, in form of the way implicit biases rely on words, that is endemic to epistemic injustice.

9 The issue's final two essays probe the nature and limits of Rorty's underappreciated contributions to the topics of education and pedagogy. Stefano Oliverio's "Dead-ending Philosophy? On Rorty's Literary Culture, Democratic Ethos and Political Education" takes up one of the core assumptions of Rorty's project - namely, that fostering a democratic ethos entails not only shifting from a predominantly philosophical to a literary culture but making edification through literature the primary means of democratic education. Oliverio insightfully compares and contrasts the educational approaches of Rorty and Dewey, but also expands the conversation using Cornelius Castoriadis as a bridge to a philosophical side of the democratic culture and ethos that Rorty may have unnecessarily rejected. The essay then develops a conception of a democratic philosophical culture oriented toward the education of citizens by drawing on the Philosophy for Children (P4C) paradigm, via Matthew Lipman and Ann Sharp, which fosters an "individualizing-critical" mode much earlier in cognitive development than Rorty's proposal for postponing "individualization" and critical thinking until post-secondary education, limiting the pre-secondary education to "socialization." On Oliverio's view, P4C practices a form of "Socratic pragmatism" closer to Dewey than Rorty and the latter's embrace of E. D. Hirsch's program of "cultural literacy." P4C offers resources to augment Rorty's narrowing of political education to the cultivation of the literary imagination and to help avoid a politicized conception of socialization which elevates the inculcation of values over their critical questioning. At the same time, Oliverio discerns how Rorty may be used to develop more fully the moral use of literary texts by rectifying P4C's neglect of "creative and caring thinking" and bias toward the analytical-logical.

In "Notes from the Playground: The Educational Process Between Contingency and Luck," Maura Striano provides an interesting and updated examination of the potentialities of Rorty's reflections on education, focusing mainly on his widely discussed distinction between socialization and individualization. Striano moves from an episode of Rorty's adolescence - one that according to Striano, Richard Bernstein would have called a "concrete social form[s] of cruelty" (1992: 287) - that probably affected Rorty's reflection: "when he was an adolescent, bullies regularly used to beat him up in the playground of his high school, an action that he was unable to avoid." In this narration Striano illuminates Rorty's invitation to "acknowledge the capacity that each individual has to create and re-create one's self, diverting one's path away from expected roles and performances." She takes it as a crucial point to investigate education as a form of "edification" that always implies a process of (re)modulation of the relationship between the individual and the society: "a process taking us 'out of our old selves by the power of strangeness, to aid us in becoming new beings' (Rorty 1979: 360)." Considering the new generation of scholars' line of interpretation, which aims to 
smooth over the contrast between the two educational phases identified by Rorty, Striano wonders what it currently means to adopt and extend Rorty's theoretical proposal in the educational field, questioning, particularly, how to interpret his insistence on the importance of "luck", which is an element constantly present in the educational process.

\section{BIBLIOGRAPHY}

AUXIER Randall E., KRAMER Eli \& Krzysztof Piotr SKOWROŃSKI (eds.), (2020), Rorty and Beyond, Lanham, MD, Lexington Books.

BERNSTEIN Richard J., (1992), The New Constellation: The Ethical-Political Horizons of Modernity/ Postmodernity, Cambridge, MA, The MIT Press.

BRODSKY Garry, (1982), “Rorty's Interpretation of Pragmatism," Transactions of the Charles S. Peirce Society, 18 (4), 311-37.

CALCATERRA Rosa Maria, (2019), Contingency and Normativity. The Challenges of Richard Rorty, Boston, Brill-Rodopi.

CHIN Clayton, (2018), The Practice of Political Theory: Rorty and Continental Thought, New York, Columbia University Press.

CURTIS William M., (2015), Defending Rorty: Pragmatism and Liberal Virtue, New York, Cambridge University Press.

MALACHOWSKI Alan (ed.), (2020), A Companion to Rorty, Malden, MA, Wiley-Blackwell (Blackwell Companions to Philosophy).

MARCHETTI Giancarlo (ed.), (forthcoming), The Ethics, Epistemology and Politics of Richard Rorty, New York, Routledge.

MCCLEAN David E., (2016), Richard Rorty, Liberalism, and Cosmopolitanism, New York, Routledge.

REY Santiago, (2017), “Rorty the Outrageous," Contemporary Pragmatism, 14 (3), 307-18.

RONDEL David (ed.), (forthcoming), A Cambridge Companion to Rorty, New York, Cambridge University Press.

RORTY Richard, (1979), Philosophy and the Mirror of Nature, Princeton, Princeton University Press. RORTY Richard, (2020), On Philosophy and Philosophers: Unpublished Papers, 1960-2000, edited by W.P. Małecki \& Chris Voparil, New York, Cambridge University Press.

SCHULENBERG Ulf, (2015), Romanticism and Pragmatism: Richard Rorty and the Idea of a Poeticized Culture, London, Palgrave MacMillan.

SKOWROŃSKI Krzysztof Piotr, (2015), Values, Valuations, and Axiological Norms in Richard Rorty's Neopragmatism, Lanham, MD, Lexington Books. 


\section{NOTES}

1. Recently published books on Rorty include: Calcaterra (2019); Chin (2018); Curtis (2015); McClean (2016); Schulenberg (2015); and Skowroński (2015).

2. See Malachowski (2020) and Auxier, Kramer \& Skowroński (2020). Books by Rondel and by Marchetti are forthcoming.

\section{AUTHORS}

\section{MICHELA BELLA}

Università del Molise

michela.bella[at]unimol.it

\section{CHRIS VOPARIL}

Union Institute \& University

chris.voparil[at]myunion.edu 